\title{
Polyetherols from melamine cyanurate and ethylene carbobate - synthesis and application
}

\author{
Dorota Kijowska, Izabella Legocka \\ Department of Polyester, Epoxides and Polyurethanes, Industrial Chemistry Research Institute, ul. Rydygiera 8, 01-793 \\ Warszawa, Poland, e-mail: dorota.kijowska@ichp.pl
}

\begin{abstract}
The results of the study on the reactions of melamine cyanurate with ethylene carbonate were presented. As a result of the reactions, polyetherols containing thermostabile 1,3,5-triazine and perhyroxo-1,3,5-triazine rings in their structure were obtained. Basic physical properties such as density, viscosity, hydroxyl number, weight changes were measured. The polyetherols were applied as a polyol component to receiving of thermoresistant polyurethane foams. Some of the properties of the obtained foams were investigated. The value of the apparent density is between 51 and $71 \mathrm{~kg} / \mathrm{m}^{3}$, compressive strength $222-356 \mathrm{kPa}$ and the content of the open pores between $14-33 \%$. Thermal resistance was also studied by means of the TGA method. It was found that oxygen index of the selected compositions is between $20-22 \%$.
\end{abstract}

Keywords: melamine cyanurate, ethylene carbonate, polyetherols, polyurethane foams.

\section{INTRODUCTION}

Melamine cyanurate (MC) is successfully applied as an agent increasing thermal resistance of plastics because of the presence of $50 \%$ nitrogen and of s-triazine as well as perhydro-1,3,5-triazine rings ${ }^{1-4}$. An example of plastics for which the increased resistance to thermal degradation is desirable, is polyurethane foam. There are reports in literature $^{5,6}$ concerning the application of powdered MC to obtain polyurethane foams. However, insertion of solid into polyols master batches causes a significant increase of their density, which may cause clogging of the nozzles giving polyol blend. Transfer of MC in the reaction with ethylene carbonate into liquid polyetherols could solve the problem. The polyetherols could be successfully applied as a polyol component to foamed polyurethane plastics. Thermostabile striazine and perhydro-1,3,5-triazine rings introduced in this way should affect the increase of the thermal resistance of the foams obtained.

Alkylene carbonates (AC) of general formula (I) are cyclic esters of carbonic acid and appropriate vicinal dioles:<smiles>[R]C1COC(=O)O1</smiles>

Such AC as ethylene carbonate and propylene carbonate are excellent solvents of many low molecular compounds as well as polymers because of their polar character ${ }^{7}$. Due to non-toxicity propylene carbonate is used as a solvent of paints, varnishes and plastics ${ }^{8}$. AC are also used as modifiers in the production of solid, fast cross-linking polyurethanes as well as of polyurethane adhesives.

Alkylene carbonates were proved to be also suitable for hydroxyalkylation of azacyclic compounds. The route of the reaction depends on the temperature of the reaction, and kind of the catalyst and the structure of A group:

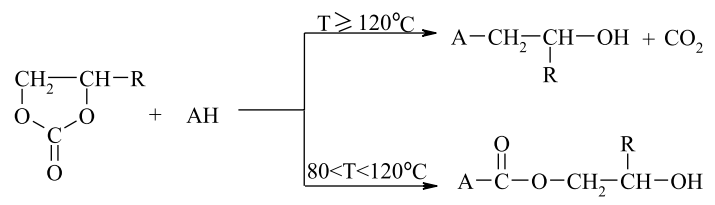

where:

$\mathrm{R}=-\mathrm{H},-\mathrm{CH}_{3}$.

Reactions accompanied by carbon dioxide evaluation usually run at the temperature over $100^{\circ} \mathrm{C}$ (in the case of amines within the range $140-170^{\circ} \mathrm{C}$ with or without an alkaline catalyst $\left.{ }^{9}\right)$.

$\mathrm{MC}$ is a compound containing active hydrogen atoms, obtained by a direct reaction of melamine with cyanuric acid in an aqueous solution.

This paper presents the synthesis of polyetherols based on $\mathrm{MC}$ and ethylene carbonate as a hydroxyalkilating agent as well as the application of the obtained polyetherols to foam polyurethane plastics.

\section{EXPERIMENTAL}

\section{Synthesis of Polyetherols}

In a $500 \mathrm{~cm}^{3}$ reactor equipped with a mechanical stirrer and reflux condenser, $25.5 \mathrm{~g}$ (0.1 mole) melamine isocyanurate, appropriate amount of ethylene carbonate (EC) (158.4 g (1.8 mole); $176 \mathrm{~g}$ (2.0 mole); 211,2 g (2.4 mole) or $422,4 \mathrm{~g} \quad(4.8$ mole $)$ and catalyst $(1,4-$ diazabicyclo[2.2.2] octane (DABCO)) (2; 4 or $8 \mathrm{~g} / \mathrm{mole}$ $\mathrm{MC}$ were placed. The reaction mixture was heated to an appropriate temperature $\left(160^{\circ} \mathrm{C}, 165^{\circ} \mathrm{C}\right.$ or $170^{\circ} \mathrm{C}$.). The progress of the reaction was monitored by the IR spectral measurements of aliquots until the band of valence vibrations of ethylene carbonate carbonyl group at $1790 \mathrm{~cm}^{-1}$ disappeared. For the same polyetherols hydroxyl number was determined.

\section{Foam Preparation}

Attempts of foaming were carried out in small $500 \mathrm{~cm}^{3}$ test cups at room temperature. To a sample of $10 \mathrm{~g}$ of a polyol, 1.5 wt $\%$ of surfactant, $0.15-0.47$ wt $\%$ of triethylamine - catalyst and $2 \mathrm{wt} \%$ of water were added. As a polyol component a mixture consisting of polyetherol obtained in the reaction of $\mathrm{MC}$ with ethylene carbonate and other polyesterols (Poles 50/23, Poliester 350) or polyetherols (Rokopol D2002, Rokopol G500) was used. As a surfactant PC Stab EP05 was used. After careful 
mixing of the components, a pre-weighed amount of 4,4'diphenylmethane diisocyanate (MDI) was added.

\section{Analytical Methods}

The reaction of MC with EC and PC was monitored by the determination of EC. ${ }^{1} \mathrm{H}-\mathrm{NMR}$ and the spectra of the products were recorded with spectrometer NMR Varian Unity Plus $200 \mathrm{MHz}$ in deuterated chloroform $\left(\mathrm{CDCl}_{3}\right)$, and hexamethyldisiloxane (HMDS) reference.

Thermal analyses (DTA, DTG, and TG) of polyetherols and polyurethane foams were performed in a ceramic crucible at $20-700^{\circ} \mathrm{C}$ temperature range, with 100 min registration time, $200 \mathrm{mg}$ sample, under air atmosphere with TGA Q50 V20.8, Bulid 34 derivatograph. The following properties of polyetherols were determined: pycnometer density $^{10}$, Hôppler viscosity ${ }^{11}$ and hydroxyl number ${ }^{12}$. The following properties of foams were determined: apparent density $^{13}$, compressive strength ${ }^{14}$, content of open pores ${ }^{15}$, oxygen index ${ }^{16}$ (Fire Testing Technology Limited, UK).

\section{Results}

From the literature review, concerning physical and chemical properties of alkylene carbonates ${ }^{\mathbf{8}, 9}$, the compounds should be good solvents for $\mathrm{MC}$ and react with it towards polyetherols formation:

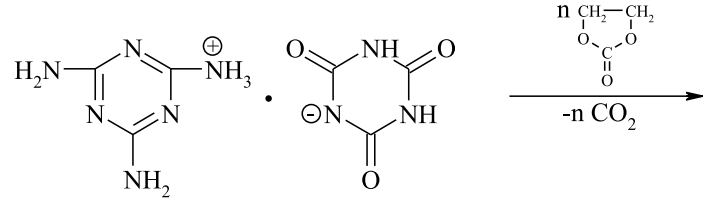

where: $\mathrm{x}+\mathrm{y}+\mathrm{z}+\mathrm{w}+\mathrm{p}+\mathrm{q}+\mathrm{r}=\mathrm{n}, 0<\mathrm{r}<1$, $\mathrm{n}=\mathrm{n} 0-\mathrm{n}^{\prime}$,

$\mathrm{n}$ - number of moles of ethylene carbonate, which reacted with MC

$\mathrm{n}_{0}$ - initial number of moles of ethylene carbonate,

$\mathrm{n}^{\prime}$ - number of moles of ethylene carbonate, which was decomposed

As expected, the reaction proceeded without the solvent. The reaction was carried out with or without the catalyst. As the catalyst 1,4-diazabicyclo-[2.2.2]octane (DABCO) was used. In Table 1 the conditions of the reaction are presented.

It has been stated that $\mathrm{MC}$ is very well digested in hot EC giving polyetherols. On the bases of $1 \mathrm{H}-\mathrm{NMR}$ spectrum it has been stated that carbonate groups are built in the struc- ture of the product, however the amount of the groups does not exceed $1 \mathrm{~mole} / \mathrm{mole}$ of product.

As it follows from the data of Table 1, the product mass, found from mass balance, is less than that one calculated from the initial molar ratio of reagents. This means that in the initial phase of the reaction a part of alkylene carbonate decomposes to the easily volatile ethylene oxide:

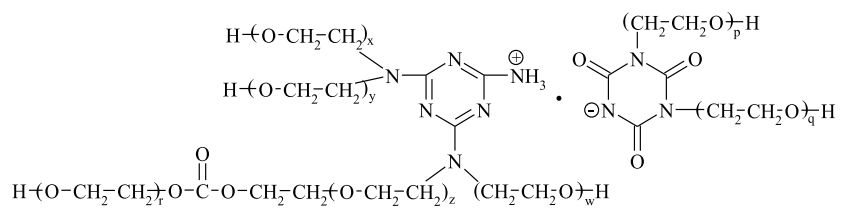

From the literature ${ }^{17}$, the degree of decomposition depends on the kind of the catalyst used, and on the structure of alkylene carbonate. From the data of table 1, the largest decomposition is for $170^{\circ} \mathrm{C}$ without a catalyst.

Liquid, dark brown substances similar to resins have been obtained as the result of the synthesis. Some of the properties of the selected polyetherols, such as density, viscosity and hydroxyl number, obtained in the paper are presented in Table 2.

Thermal resistance of polyetherols obtained has been also determined by means of thermo gravimetric analysis. On the plot of TGA analysis of pure MC one endothermic peak derived from s-triazine and perhyroxo-1,3,5-triazine rings, decomposition is observed. A maximum of the peak occurs at $410^{\circ} \mathrm{C}$ (Fig. 1). In the case of polyetherols two endothermic peaks are observed (Fig. 2). The first one at $262^{\circ} \mathrm{C}$, refers to the decomposition of polyetherols chains, and the second one at $383^{\circ} \mathrm{C}$ to the decomposition of MC ring.

The results presented above indicate that polyetherols obtained in this work are suitable to receive foamed polyuretanes with increased thermal resistance.

If as a polyol component only the polyetherol obtained form $\mathrm{MC}$ and $\mathrm{EC}$ has been applied, the compositions were too reactive and foam increase took place before reaching an appropriate degree of cremation. The foam obtained was characterized by a low degree of foaming and heterogeneity. In order to lengthen the composition growth time other polyols components were applied. Addition of Poles 50/23 caused a double increase in composition growth time and application of dibutyltin laurate as a catalyst prevented the foam collapsing. Longer times were obtained, when Rokopol

Table 1. The conditions of MC reaction with ethylene carbonate (EC)

\begin{tabular}{|c|c|c|c|c|c|c|c|}
\hline Run & $\begin{array}{l}\text { Initial molar } \\
\text { ratio of } \\
\text { MC:EC } \\
\end{array}$ & $\begin{array}{c}\text { Amount of } \\
\text { catalyst } \\
{[\mathrm{g} / \mathrm{mole} \mathrm{MC}]}\end{array}$ & $\begin{array}{c}\text { Temperature } \\
{\left[{ }^{\circ} \mathrm{C}\right]}\end{array}$ & $\begin{array}{c}\text { Reaction } \\
\text { time } \\
{[\mathrm{h}]}\end{array}$ & $\begin{array}{c}\text { Time of MC } \\
\text { dissolution } \\
\text { [min.] } \\
\end{array}$ & $\begin{array}{c}\text { Number of moles of EC } \\
\text { decomposed } \\
\text { [mole/mole } \mathrm{MC}] \\
\end{array}$ & $\begin{array}{l}\text { Effective number of } \\
\text { moles of EC reacted }\end{array}$ \\
\hline 1. & $1: 18$ & 8 & 170 & 7 & 30 & 1.4 & 16.6 \\
\hline 2. & $1: 18$ & 8 & 160 & 8 & 40 & 0.7 & 17.3 \\
\hline 3. & $1: 18$ & 4 & 170 & 8 & 25 & 1.2 & 16.8 \\
\hline 4. & $1: 18$ & 4 & 160 & 8.5 & 50 & 1.0 & 17.0 \\
\hline 5. & $1: 20$ & - & 170 & 10.5 & 50 & 1.4 & 18.6 \\
\hline 6. & $1: 24$ & 2 & 160 & 8 & 30 & 0.5 & 23.5 \\
\hline 7. & $1: 48$ & 2 & 165 & 11 & 20 & 0.5 & 47.5 \\
\hline
\end{tabular}

Table 2. The properties of polyetherols obtained from MC and EC

\begin{tabular}{|l|c|c|c|c|c|c|}
\hline Series & $\begin{array}{c}\text { Initial molar ratio } \\
\text { MC:EC }\end{array}$ & $\begin{array}{c}\text { Amount of catalyst } \\
{[\mathrm{g} / \mathrm{mole} \mathrm{MC}]}\end{array}$ & $\begin{array}{c}\text { Temperature } \\
{\left[{ }^{\circ} \mathrm{C}\right]}\end{array}$ & $\begin{array}{c}\text { Density } \\
{\left[\mathrm{g} / \mathrm{cm}^{3}\right]}\end{array}$ & $\begin{array}{c}\text { Viscosity } \\
{[\mathrm{cP}]}\end{array}$ & $\begin{array}{c}\text { Hydroxyl value } \\
{[\mathrm{mg} \mathrm{KOH} / \mathrm{g}]}\end{array}$ \\
\hline 1. & $1: 20$ & - & 170 & 1.05 & 980 & 420 \\
\hline 2. & $1: 24$ & 2 & 160 & 1.10 & 1050 & 380 \\
\hline
\end{tabular}




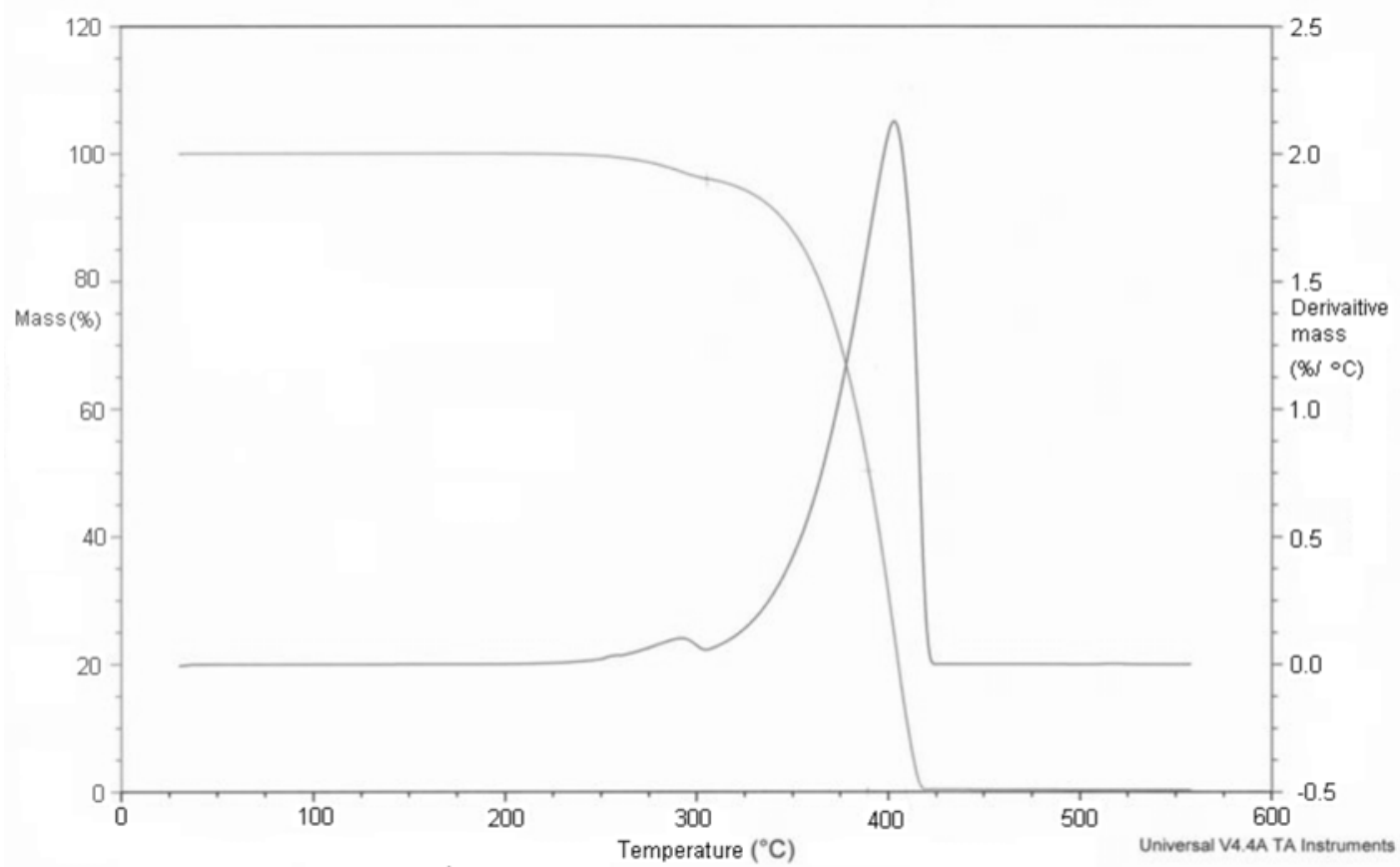

Figure 1. TGA plot of MC

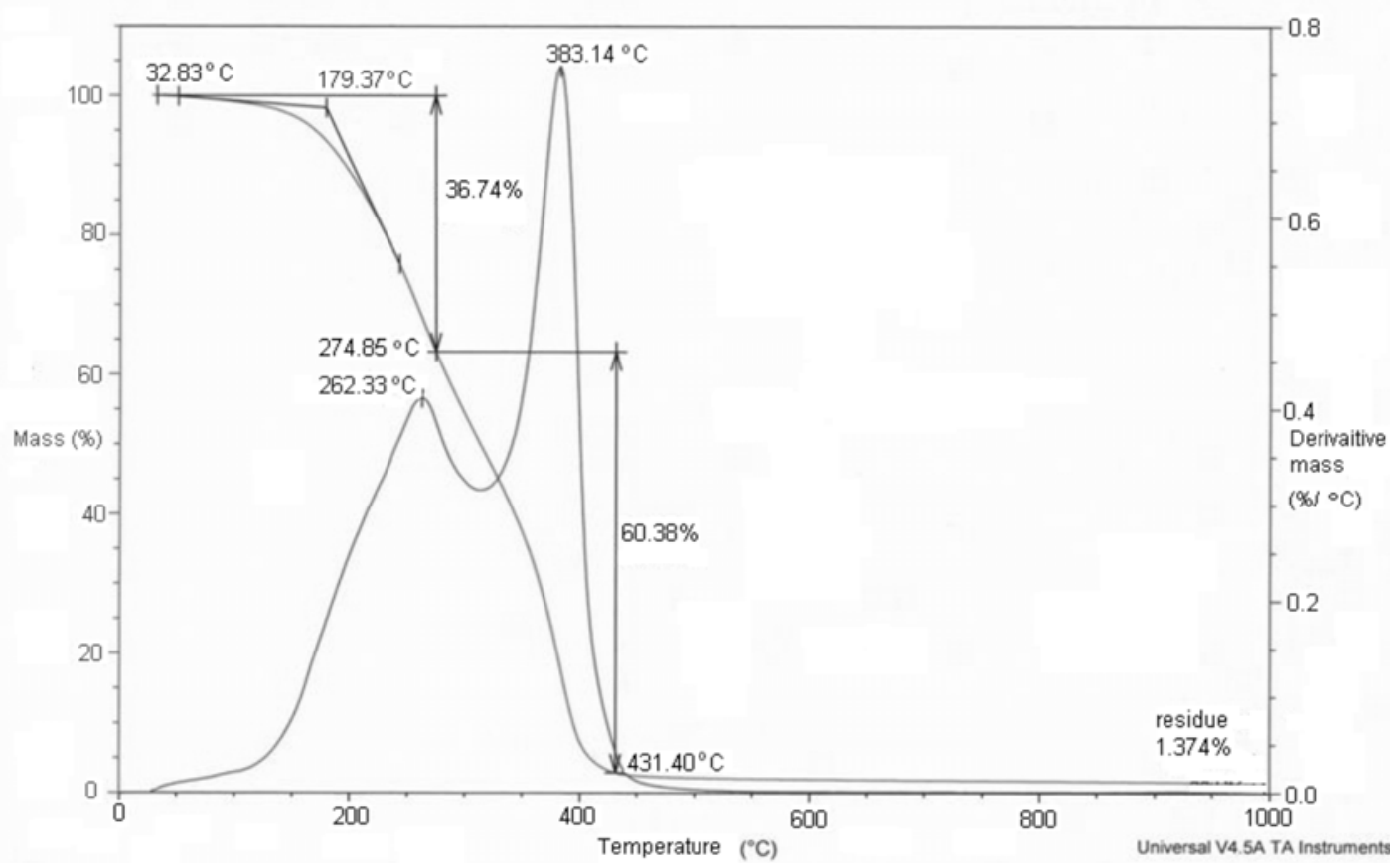

Figure 2. TGA plot of polyetherole obtained from MC and EC

D 2002 were applied, however the amounts greater than $20 \mathrm{~g} / 100 \mathrm{~g}$ polyole mixture caused big polymerization shrinkage of the foam. A good foaming degree was obtained for Rokopol G 500 and Polyester 350 applied as the additions.

Some properties of the selected foams, such as apparent density, compressive strength, (parallel and perpendicular to growing) oxygen index and content of open pores were determined. The results are collected in Table 3 .

An apparent density of the foams obtained is within the range $50-100 \mathrm{~kg} / \mathrm{m}^{3}$, which classifies them to the rigid or semi- rigid ones. In turn compressive strength falls within the range $220-360 \mathrm{kPa}$ and is characteristic for the rigid foams.

A thermal resistance of the foams has been also examined by the TGA method. In Figures 3,4, additions of other polyesterols or polyetherols to the polyol compositions obtained from MC do not have a negative impact on the thermal resistance of the obtained foams. In the case of polyurethane foam obtained from polyol mixture, containing an addition of Rokopol D 2002, 50\% weight loss takes place at $386^{\circ} \mathrm{C}$. In turn, in the case of polyurethane foam obtained with the addition of Polyester 350, 50\% weight loss takes place at $403^{\circ} \mathrm{C}$.

It is concluded that the introduction of s-triazine and perhydro-1,3,5-triazine rings to the structure of MC causes a significant improvement of thermal resistance of the foams obtained with the participation of polyetherols synthesized from $\mathrm{MC}$ and $\mathrm{EC}$, as compared with traditional polyurethane foams, whose thermal resistance is $120^{\circ} \mathrm{C}$ only. 
Table 3. Properties of the selected foams

\begin{tabular}{|c|c|c|c|c|c|c|c|c|}
\hline Run & $\begin{array}{l}\text { Polyetherol from } \\
\text { MC and EC/ } \\
\text { other polyetherol } \\
\text { or polyesterol } \\
\text { [wt parts } / 100\end{array}$ & $\begin{array}{c}\text { Amount of } \\
\text { MDI } \\
\text { [g/100 g } \\
\text { polyol] }\end{array}$ & $\begin{array}{c}\text { Amount of } \\
\text { catalyst } \\
\text { [g/100 g } \\
\text { poliol] }\end{array}$ & $\begin{array}{c}\text { Apparent } \\
\text { density } \\
{\left[\mathrm{kg} / \mathrm{m}^{3}\right]}\end{array}$ & $\begin{array}{c}\text { Compressive } \\
\text { strenght } 10 \% \\
\text { compression, } \\
{[\mathrm{kPa}]} \\
\text { parallel to growing }\end{array}$ & $\begin{array}{l}\text { Compressive } \\
\text { strenght } 10 \% \\
\text { compression, } \\
{[\mathrm{kPa}]} \\
\text { perpendicular to } \\
\text { growing } \\
\end{array}$ & $\begin{array}{c}\text { Oxygen } \\
\text { index } \\
{[\%]}\end{array}$ & $\begin{array}{c}\text { Content of } \\
\text { open pores } \\
{[\%]}\end{array}$ \\
\hline \multicolumn{9}{|c|}{ ROKOPOL D 2002} \\
\hline 1. & $80 / 20$ & 112 & 0.15 & 63.8 & 222 & 196 & 22.1 & 19.4 \\
\hline \multicolumn{9}{|c|}{ ROKOPOL G 500} \\
\hline 2. & $50 / 50$ & 118 & - & 51.3 & 356 & 274 & $<20$ & 15.7 \\
\hline 3. & $80 / 20$ & 125 & - & 54.6 & 307 & 271 & $<20$ & 14.6 \\
\hline \multicolumn{9}{|c|}{ POLYESTER 350} \\
\hline 4. & $50 / 50$ & 123 & - & 55.4 & 278 & 205 & 21.7 & 33.2 \\
\hline 5. & $80 / 20$ & 126 & - & 70.9 & 325 & 274 & 21.8 & 14.4 \\
\hline
\end{tabular}

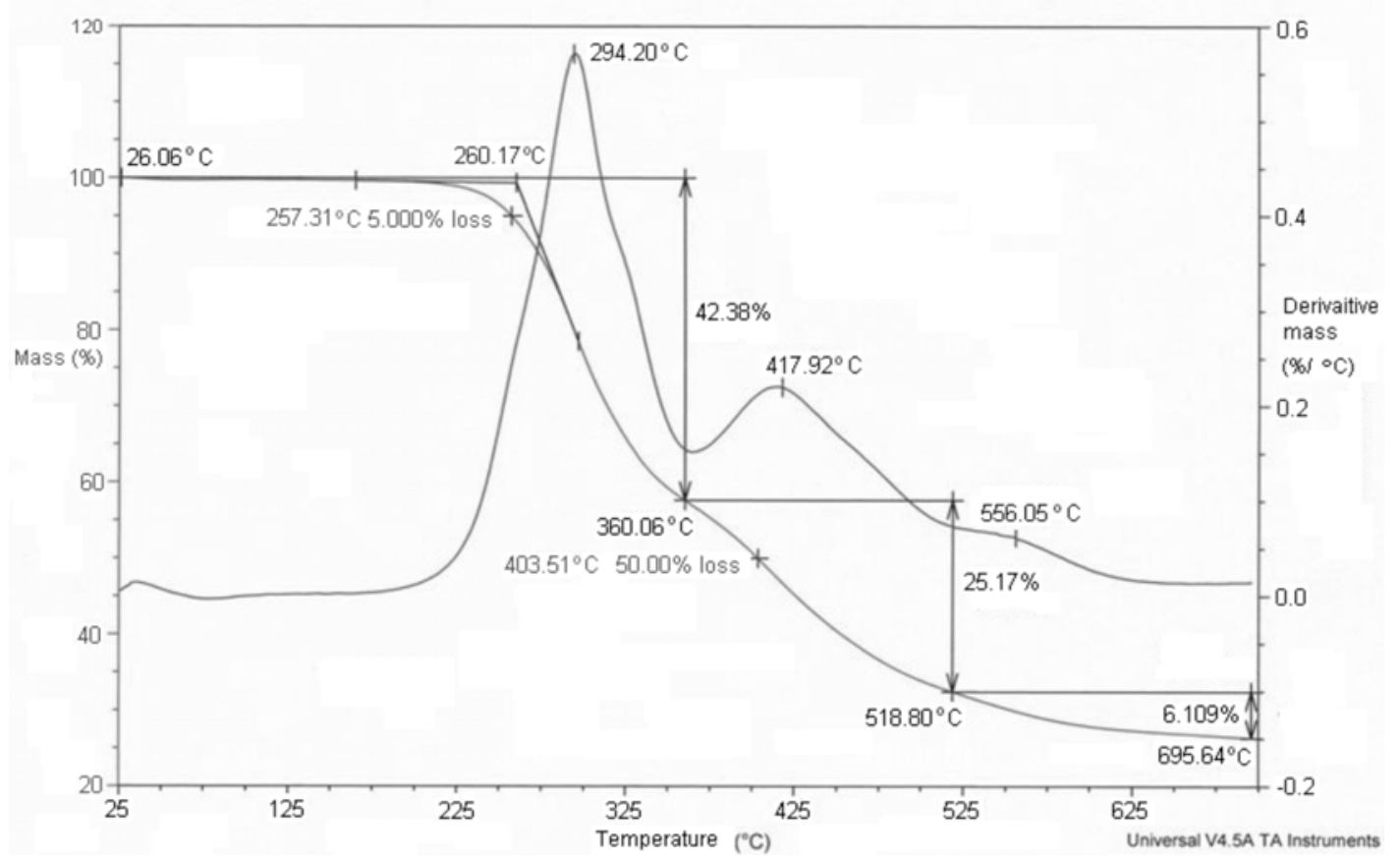

Figure 3. Plot of TGA for the foam obtained from polyol mixture with $50 \mathrm{wt} \%$ of POLYESTER 350

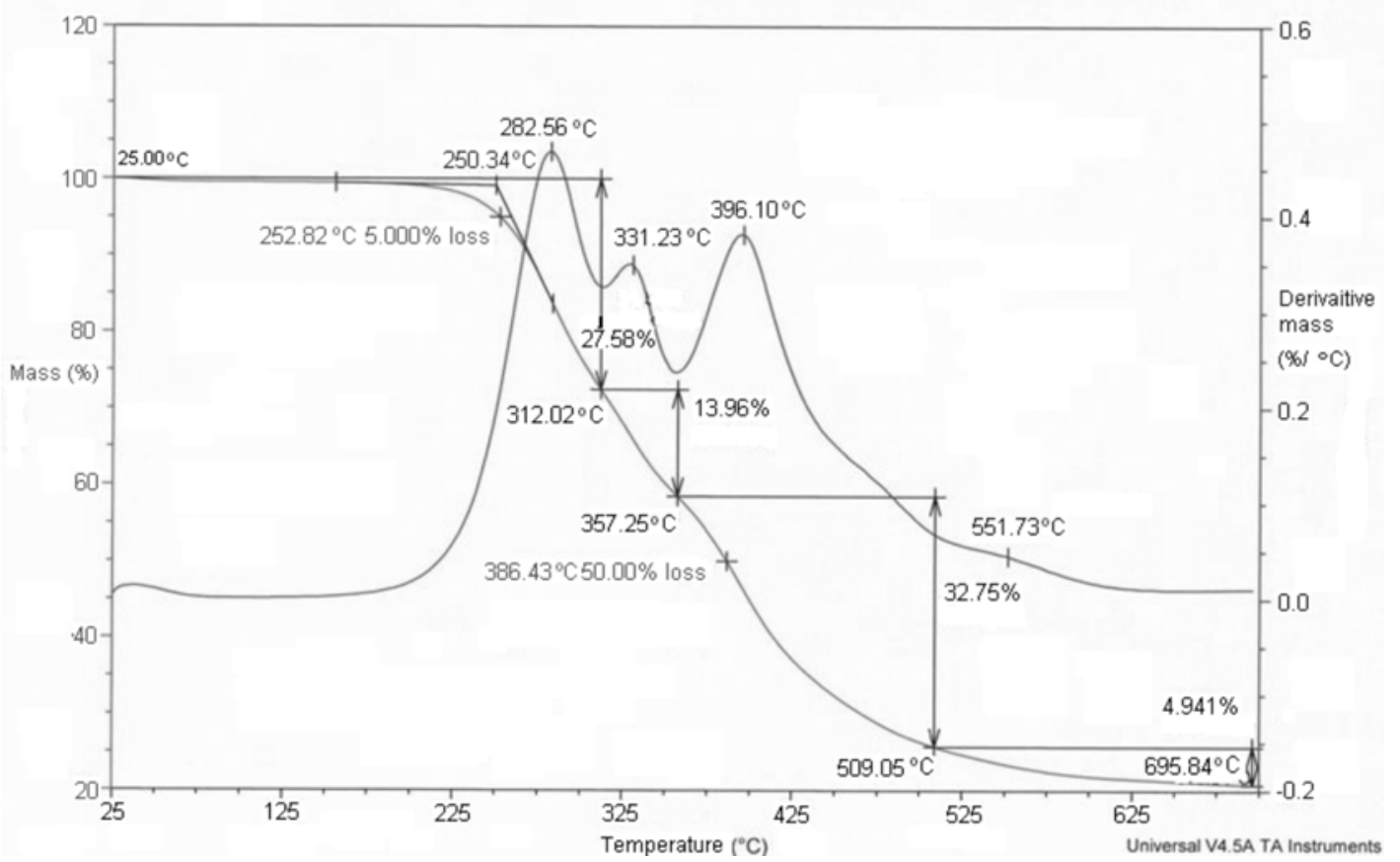

Figure 4. Plot of TGA for the foam obtained from polyol mixture with 20 wt $\%$ of ROKOPOL D 2002 


\section{CONCLUSIONS}

1. MC reacts with EC towards polyetherols containing striazine and perhydro-1,3,5-trazine rings in their structure, while carbonate groups are built in the structure of the product, however the amount of the groups does not exceed 1 mole/mole of product.

2. Physical parameters of the obtained polyetherols as well as their thermal analysis indicate that the compounds are suitable to receive foamed polyurethanes with increased thermal resistance.

3. The use of other polyetheroles or polyesteroles to reduce the reactivity of the synthesized polyetherole caused an extension of the time of composition as well as obtaining more homogeneous foam.

4. The obtained foams are characterized by a much higher thermal resistance than the traditional polyurethane foams.

\section{LITERATURE CITED}

1. Casu, A., Camino, G., De Giorgi, M., Flath, D., Morone, V., Zenoni, R., Fire-retardant mechanistic aspects of melamine cyanurate in polyamide copolymer. Polym. Degrad. Stab., 58 (1997), 297-302, DOI:10.1016/S0141-3910(97)00061-X.

2. Roland, W., Reinhard, B., Andreas, D. (2007). EP No. 1731559. European Patent Office.

3. Morival, G., Hervy, C. (1988). US Patent No. 4786673. Washington, D.C.: U.S. Patent and Trademark Office.

4. Kasowski, R., Martens, M. (2000). US Patent No. 3,025,419. Washington, D.C.: U.S. Patent and Trademark Office.

5. Modesti, M., Lorenzetti, A., Simioni, F. and Checchin, M. (2001). Influence of different flame retardants on fire behaviour of modified PIR/PUR polymers. Polym. Degrad. Stab. 74(3), 475-479, DOI:10.1016/S0141-3910(01)00171-9.

6. Zatorski, W., Brzozowski, Z. (2003). Pol. Patent No. 198605. Warsaw, Patent Office of The Republic of Poland.

7. Mazo, G.Y., Ross, R.J., Kneller, J.F., Mazo, J. (1999). U.S. Patent No. 5,939,517. Washington, D.C.: U.S. Patent and Trademark Office.

8. Klimiec, J., Fabisz, E., Researches on synthesis of propylene carbonate. Chem. Ind. 79 (10) 339-340 2000.

9. Clements, J.H. Reactive Applications of Cyclic Alkylene Carbonates. Ind. Eng. Chem. Res. (2003). 42 (4), pp 663-674, DOI: $10.1021 / \mathrm{ie} 020678 \mathrm{i}$.

10. Kowalski, P. (2004). Laboratory of Organic Chemistry; WNT: Warsaw, (in Polish).

11. Kocot-Bończak, D. (1977). Laboratory Experiments in Physical Chemistry PZWL: Warsaw, (in Polish).

12. Polish Committee for Standardization (1993). Polish Standards: Polyethers for polyurethanes - Test methodsDetermination of hydroxyl number. PN-C-89052-03: Method A. Poland.

13. Polish Committee for Standardization (1999). Polish (European) Standards: Products for thermal insulation for building - Determination of apparent density. PN-EN 1602. Poland.

14. Polish Committee for Standardization (1998). Polish (European) Standards: Products for thermal insulation for building - Determination of behavior during compression. PN-EN 826. Poland.

15. Polish Committee for Standardization (2005). Polish Standards: Rigid porous plastics - Determination of percentage volumetric content of open and closed cells. PN-ISO 4590. Poland.

16. Polish Committee for Standardization (2006). Polish (European) Standards: Plastics - Determination of flamma- bility by oxygen index - Part 2: Test at room temperature. PNEN ISO 4589-2. Poland.

17. Mc Entire, E.E., Gipson, R.M. (1981). U.S. Patent No. 4265821 Washington, D.C.: U.S. Patent and Trademark Office. 